PROCEEDINGS, INDONESIAN PETROLEUM ASSOCIATION

rowenty-Sixth Annual Convention, May 1998

\title{
CHARACTERIZATION OF BACTERIAL ISOLATE FROM WASTE WATER AT OIL DRILLING WELL FOR DECREASING OIL VISCOSITY
}

\author{
Nuryati Juli* \\ Septoratno Siregar* \\ Eswar Roezxaman*
}

\begin{abstract}
In the study, eleven bacterial isolates were treated onto two types of parafinic hydrocarbon (X1 \& X2). All bacteria were isolated from waste water at oil drilling well sights as facultative anaerobic and thermophilic strains. All bacteria were adapted in two ways :
\end{abstract}

1. A mixed culture was adapted into a crude oilmolases medium.

\footnotetext{
Institute Technology Bandung
}

2. The adapted mixed culture was re-adapted into a crude oil medium without molases.

The bacterial culture were incubated at $55^{\circ} \mathrm{C}$ for 14 days. Kinematic viscosity was used as a paramete. The results showed that the viscosity of both parafinic hydrocarbon types were decreased. However, the decreased viscosity for X2 was higher than X1. Decreased viscosity in the crude oil-molases medium was lower than in crude oil-only medium. The greatest oil viscosity decrease was $39.56 \%$, which occurred in $\mathrm{X} 2$ crude oil-only medium.

Based on these results, it is concluded that each bacterial characteristic and their affects on hydrocarbons are very specific and cannot be generalized for all oil fields. 